\title{
Bulanık MOORA Yöntemi Kullanılarak Yeşil Tedarikçi Geliştirme Programlarının Seçimi ve Değerlendirilmesi
}

\section{Evaluating And Selection Of Green Supplier Development Programs By Using Fuzzy MOORA}

\author{
Bilal Şişman, Afyon Kocatepe Üniversitesi , Türkiye, bilalsis@ hotmail.com
}

\begin{abstract}
$\ddot{O}_{z}$ : Yeşil tedarik zinciri yönetiminde tedarikçilerin çevresel performanslarını gelişstirmek oldukça önemlidir. Günümüz işletmeleri tedarikçilerinin performansların iyileştirmek ve geliştirmek için çok farkl tedarikçi geliştirme programlarına yatırımlar yapmaktadırlar. Yeşili seven ve çevreyi önemseyen tedarikçilerin olması işletmelerin rekabet avantajı elde etmelerinde ilk sırada yer alan konulardan biri durumundadır. Fakat yeşil tedarikçi geliștirme programları arasindan doğru tercihte bulunmak ve bunu uygulamaya koymak tecrübesizlik, geçmiş deneyimlerde başarısızlık, sinırlı düzeyde bilgi, kurumsal altyapı eksikliği gibi sebeplerden dolayı oldukça zor olmaktadır. Çalışmanın amacı belirsizlik ortamında nominal grup tekniği ve bulanı MOORA yöntemi ile uzmanlar tarafindan öngörülen çeşitli yeşil tedarikçi gelişstirme programlarını değerlendirmektir. İlk olarak nominal grup tekniği ile yeşil tedarikçi geliş̧tirme programları değerlendirmek için bazı kriterler belirlenmiştir. Ardından nicel verilerin yetersiz olduğu belirsizlik ortaminda alternatif programların siralanması ve değerlendirilmesi amactyla bulanı MOORA yönteminden yararlanılmıştır. Son olarak modelde yer alan kriter ağırllklarının alternatif programlar üzerindeki etkinliğini incelemek ve test etmek için duyarlılık analizi yapılmıștır.
\end{abstract}

Anahtar Sözcükler: Yeşil Tedarikçi Geliştirme, Nominal Grup Tekniği, Bulanık MOORA,

\begin{abstract}
Developing environmental performance of suppliers is essential for green supply chain management. Today's enterprises are investing very different supplier development programs to improve and enhance the performance of their suppliers. The existences of suppliers which care about environment and are green lover's issues have been ranked firstly to achieve competitive advantage for businesses. The decision to select and implement among the right green supplier development programs is challenging due to lack of prior experience and institutional structure, limited information and varying supplier backgrounds. The aim of this paper is to evaluate various green supplier development programs projected by experts based with nominal group technique and fuzzy MOORA under uncertain environment. Nominal group technique is used firstly to identify criteria for evaluating green supplier development programs. Then, fuzzy MOORA is utilized in order to generate green supplier development program ranking and evaluating under lack of quantitative information. Lastly, sensitivity analysis is addressed to determine and test the influence of criteria weights on alternative programs in the model parameters.
\end{abstract}

Keywords: Green Supplier Development, Nominal Group Technique, Fuzzy MOORA

\section{Giriş}

Avrupa Birliği başta olmak üzere tüm dünyada WEEE (European Union Directive on Waste Electrical and Electronic Equipment) programları, RoHS (Restriction of Hazardous Substances) yasaları, ISO 14000 standartları gibi çevresel uygulamalar işletmeleri imalat süreçlerinde ve tedarik zincirlerinde çevreye daha dostça davranmalarına zorlamaktadır. Bu sebeple yazılı ve görsel medyanın baskısı, zorlu rekabet ortamı ve yasal düzenleyicilerin etkisi kurumların yeşil tedarik zincirine ilgisini sürekli olarak artırmaktadır. Bununla birlikte işletmeler imalat, pazarlama, satın alma, lojistik gibi süreçlerde çevreye zararlı madde salınımını azaltmak amacıyla çevresel programlar geliştirmekte ve yatırımlar yapmaktadırlar (Noci, 1997).

Özellikle imalat sektöründe bulunan işletmeler hammadde-malzeme alımı, yarı mamullerin taşınması, işgücünün nakledilmesi gibi faaliyetlerinin pekçok aşamasında ekonomik açıdan güçlü ve sürdürülebilir tedarikçiler tercih etmektedirler. Örneğin, tedarikçilerden satın alınan hammadde içerisindeki tehlikeli madde miktarı tedarik zinciri sürecinde ciddi çevresel ve ekonomik sorunlara sebep olabilmektedir. Diğer taraftan, uzmanlaşmamış veya tecrübesiz çalışanların olduğu tedarikçiler ile işbirliği yapmak nihai üründe kalite problemlerine neden olabilmekte bu da müşteri memnuniyetsizliğini doğurmaktadır. Bu yüzden, sürdürülebilir tedarikçiler ile çalışmak işletmeler açısında kritik derecede önemlidir. Bu duruma ulaşılabilmesi ve uzun dönemlik işbirliklerini sağlanabilmesi için en uygun tedarikçi geliştirme programlarının uygulanması gerekmektedir (Tang ve Zhou, 2012).

Bir işletmenin çevresel performansı sadece kendi faaliyetlerini dikkate alarak değil aynı zamanda tedarikçilerinin de uygulamalarını hesaba katarak değerlendirilmelidir. Çevresel konulara önem veren ve bunları hayata geçirebilen tedarikçiler ile işbirliği içerinde bulunmak, işletmelerin çevresel performansını artırmaya yardımcı olmaktadır (Lee, 2008). Bu yüzden işletmeler tedarikçilerinden çevreye uyumluluk sertifikalarını edinmelerini ve yeşil uygulamaları tanımlamalarını istemektedirler. Fakat tüm bunların yanında, pek çok tedarikçinin çevresel faaliyetleri yerine getirebilmesi ekonomik, yasal ve teknik açıdan mümkün olamamaktadır. Böylesi durumlarda, özellikle tek başlarına çevresel performanslarını iyileştiremeye gücü yetmeyen tedarikçiler için yeşil tedarikçi geliştirme programları belirlenmekte ve işletmelerin desteği ile en uygun olanlar hayata geçirilmektedir (Fu vd., 2012).

Literatürde tedarikçi performansı ölçümü, yeşil tedarikçi seçimi ve değerlendirilmesi alanında pek çok çalışma yapılmış olmasına rağmen tedarikçi geliştirme programları üzerinde çok fazla durulmadığı görülmektedir. Hatta uluslararası literatürde sınırlı sayıda bulunan bu çalışmalarda yeşil tedarikçi geliştirme programların tedarikçiler üzerinde etkinliği ölçülmeden sadece sınıflandırılması yapılmıştır (Bai ve Sarkis, 2010; Fu vd., 2012; Dou vd., 2014). 
Literatürde bulunan bu boşluğu doldurmak, bu alana katkıda bulunabilmek, yöneticilere karar vermelerinde yardımcı olabilmek ve tedarikçilerin çevresel performanslarını artırmada destek olabilmek amacıyla çalışmada yeşil tedarikçi geliştirme programları uygulamanın yapıldığı işletmede çalışan uzmanların görüşleri 1şığında ve belirsiz koşullar altında bulanık MOORA (Multi Objective Optimization for Ratio Analysis) yöntemi ile değerlendirilmiştir. Kriterler nominal grup tekniği ile belirlenmiştir. Bu teknik, üretim planlama, talep tahmini, tedarikçi seçimi gibi alanlarda kullanılan insan görüşleri ve yargıya dayalı olan problem çözme tekniğidir. Nominal grup tekniğinde uzmanlar çok sayıda fikir üzerinde birlik sağlayarak görüşleri önemine göre sıralayabilmektedir. Ardından bulanık MOORA yöntemi ile uygulama yapılarak en uygun programlar (alternatifler) belirlenmiştir. Önerilen çok kriterli karar verme yöntemi bu alanda ulusal literatürde ilk kez kullanılmış olup ideal çözüme en yakın sonuçlar üretmiştir.

Çalışmanın geri kalan bölümleri şu şekilde organize edilmiştir. İkinci bölümde yeşil tedarik zinciri ve tedarikçi geliştirme, yeşil tedarikçi kriterleri ve değerlendirme üzerine yapılmış çalışmalar incelenmiştir. Üçüncü bölümde metodolojiden bahsedilmiştir. Dördüncü bölümde elektronik ev aletleri sektöründeki bir işletme üzerinde uygulama yapılmış, bulgular elde edilmiş ve duyarlılık analizi ile alternatif durumlar değerlendirilmiştir. Beşinci bölümde çalışmanın yönetimsel etkilerinden bahsedilmiştir. Altıncı bölümde ise sonuç, gelecek çalışmalar ve öneriler üzerinde durulmuştur.

\section{Kavramsal Çerçeve}

Çalışmanın bu bölümünde yeşil tedarik zinciri yönetimi ve tedarikçi geliştirme, tedarikçilere uygun çevresel faaliyet ve bu faaliyetlerin değerlendirilmesi ve yeşil tedarikçi performansının değerlendirilmesi üzerinde durulmuştur.

\subsection{Yeşil Tedarik Zinciri Yönetimi ve Tedarikçi Geliş̧tirme Programları}

Son dönemlerde üreticilerin ve tedarikçilerin çevre yönetimi konusunda hassasiyetleri çok daha fazla tartışılır ve incelenir hale gelmiştir. Doğaya saygılı işletme olabilmek çevreye dost ürün ve hizmet geliştirebilme, temiz enerji kullanımı, ambalaj atıklarının tekrar kullanımı, geri dönüşüm faaliyetleri, tehlikeli maddelerin sınırlandırılması gibi pek çok konuda çalışma ve proje geliştirmekten geçmektedir. İşletmeler yeşil tedarik zinciri yönetimi anlayışı ile tedarikçilerinden ve dağıtım ağlarındaki diğer işletmelerinden çevreye duyarlı hareket etmelerini beklemektedirler (Erdal, 2014: 367).

Yeşil tedarik zinciri yönetimi genel olarak çevresel standartlara uygun davranan veya çevresel performansını önemseyen tedarik zincirine bağlı üyelerin faaliyetlerinin planlanması, organize edilmesi, yürütülmesi ve kontrol edilmesi şeklinde tanımlanmaktadır (Hsu ve Hu, 2009). Diğer taraftan Srivastava (2007) yeşil tedarik zinciri yönetimini, ürün tasarımı, malzeme satın alma ve seçimi, imalat süreçleri, nihai ürünlerin müşterilere teslimi ve yaşam süresi sona ermiş ürünlerin tekrar değerlendirilmesi gibi tedarik zinciri faaliyetlerini daha çevresel düşünmek şeklinde ifade etmektedirler. Linton vd. (2007) ise yeşil tedarik zinciri yönetiminde atık yönetimi, geri dönüşüm, tekrar kullanım, yeşil satın alma, yeşil imalat ve dağıtım, tersine lojistik gibi faaliyetlerin bulunması gerektiğini savunmaktadırlar. Görüldüğü üzere yeşil tedarik zinciri yönetimi tedarik zincirinde çevresel konular üzerinde yoğunlaşmaktadır. Yeşil tedarik zinciri yönetimi sayesinde kaynak kullanımında tasarruf, nihai ürünlerde değer artışı, geri dönüşüm ile enerji tasarrufu gibi kazanımların elde edilebileceği araştırmacılar tarafından savunulmaktadır (Büyüközkan ve Vardaloğlu, 2008).

Rekabet ortamının sürekli olarak artması, işletmeleri kendilerine en çok fayda sağalyacak tedarikçiler ile çalışmaya zorlamaktadır. Tedarikçilerin veya işletme içi bazı üretim seçeneklerinin değiştirilmesi gibi seçeneklerin yanında tedarikçi performansının geliştirilmesi gibi farklı alternatif yöntemler de değerlendirilmektedir (Erdal, 2014: 396). Uzmanlar, tedarikçi performansının artırılabilmesi için tedarikçi geliştirme programlarının uygulanmasını önermektedirler (Handfield vd., 2002). Tedarikçi geliştirme, işletmeye fayda sağlayacak tedarikçileri tanımlamak, sisteme daha iyi entegre etmek, etkinliklerini artırmak ve geliştirmek için harcanan çabaları ortaya koymaktadır. Bu sayede düşük maliyet, güvenilir ve hızlı teslimat, müşteri memnuniyeti, yüksek kalite, esneklik, kaliteli hizmet, kısa ürün hayat çevrimi, operasyonlarda verimlilik gibi performans temelli bazı yararlar elde edilebilmektedir (Krause vd., 2007). Tedarikçi geliştirme tedarikçi eğitimi, sertifikalandırma, teknik ve kaliteli yönetim desteği, çevresel imalat, personel değişimi ve bilgi paylaşımı gibi programlardan oluşabilmektedir (Chen vd., 2010).

Son yillarda yüksek kalitede hizmet verebilmek, çevresel standartlara uyum sağlayabilmek ve yeşil performanslarını artırabilmek maksadıyla işletmeler tedarikçi geliştirme programlarını uygulamaktadırlar. Literatürde ise yeşil tedarikçi geliştirme üzerine yapılan ve işletmelere yardımcı olabilecek nitelikte çalışmaların sınırlı sayıda olduğu görülmektedir. Örneğin, Bai ve Sarkis (2010) kurumsal nitelik, tedarikçi geliştirme programlarının niteliği ve performans çıktıları arasındaki ilişkiyi incelemek için sıkı küme teorisini (rough set theory) kullanmışlardır. Fu vd. (2012) yeşil tedarikçi geliştirme programlarını değerlendirmek için telekomünikasyon hizmet sağlayıcılarına gri tabanlı DEMATEL yöntemini uygulamışlardır. Blome vd. (2014) yeşil tedarikçi geliştirme sonuçları olarak üst yönetim desteği ve firma performansı değerlendirmesinde karşıt görüşleri değerlendirmişlerdir. Dou vd. (2014) bulanık AHP yöntemi ile Çin'de sulama ekipmanları sektöründe lider konumunda bulunan bir işletmenin tedarikçilerinin çevresel performanslarının gelişmesine katkı sağlayacak programları belirlemiş̧lerdir. Awasthi ve Govindan (2016) yeşil tedarikçi geliştirme programlarının değerlendirilmesine yönelik bir problem geliştirmişlerdir. Probleme ait kriterlerin belirlenmesinde nominal grup tekniğinden faydalanmışlar ve alternatif programların seçimi için ise bulanık VİKOR yöntemini kullanmışlardır. Sonuçta tedarikçilere yönelik ISO 14000 Sertifikalandırma ve Çevreci Uzmanlar Tarafından Çalışanların Geliştirilmesi programları en iyi alternatifler olarak çıkmıştır. Bu çalışmaların sonucunda, işletmelerin yeşil 
tedarikçi geliştirme programları vasıtasıyla tedarikçilerinin çevresel performanslarını ve faaliyetlerini artırabilecekleri ve iyileştirebilecekleri görülmektedir. Bu iyileştirme çalışmaları düzenli ve etkin eğitimler ve öğrenilen bilgilerin diğer tedarikçiler ile paylaşılması ile mümkün gözükmektedir (Fu vd., 2012).

\subsection{Yeşil Tedarikçi Kriterleri}

Yeşil tedarik zinciri yönetimi literatüründe görüldüğü üzere işletmelerin mevcut tedarikçilerinin çevresel performanslarını artırmaya yönelik adımları ile sertifikalandırma, çevresel faaliyetleri tanımlama gibi özel konularda daha istekli olmaları yönünde cesaret vermesidir. Bazı araştırmacılar sektörde birden fazla tedarikçisi bulunan işletmeler ile yaptıkları çalışmalarda, yeşil tedarikçi seçimi ve değerlendirme konusunda işletme yöneticilerine yardımcı olacak kriterler belirlemişlerdir. Örneğin yeşil tedarikçi değerlendirme konusunda yapılan ilk çalışmalardan biri Noci (1997) tarafindan otomobil endüstrisinde gerçekleştirmiştir. Çalışmada ele alınan kriterler yeşil yetkinlikler, tedarikçilerin yeşil imajı, çevresel verimlilik ve yaşam çevrim maliyetidir. Daha sonra Humphreys vd. (2003) iletişim sektöründeki yeşil tedarikçi değerlendirme kriterleri olarak çevre kirliliğinin etkisi, üst yönetim desteği, yeşil imaj, çevresel yönetim sistemi tasarımı, çevresel yetkinlikler kriterlerini kullanmışlardır. Chiou vd. (2008) Noci'nin çalışmasını genişleterek çevresel yetkinlikler, çevresel yönetim sistemi, çevresel performans ve kurumsal sosyal sorumluluk kriterleri ile elektronik endüstrisinin tedarikçilerini değerlendirmişlerdir. Lee vd. (2009) ise elektronik endüstrisindeki yeşil tedarikçilerin değerlendirilmesi için kalite, teknoloji yeterliliği, kirlilik kontrolü, çevresel yönetim, yeşil ürünler ve çevresel yetkinlikler kriterlerini önermişlerdir. Tuzkaya vd. (2009) tedarikçi değerlendirme kriterleri olarak yeşil süreç yönetimi, yeşil ürün, yeşil imaj, çevresel yönetim sistemi, kirlilik kontrolü ve çevresel maliyet kriterlerini kullanmışlardır. Feyzioğlu ve Büyüközkan (2010) beyaz eşya imalatçısı bir işletmenin tedarikçilerini değerlendirmek için ürün maliyeti, ürün kalitesi, hizmet performansı, çevresel performans kriterlerini kullanmışlardır.

Chen vd. (2010) elektronik sektöründeki bir işletmenin yeşil tedarikçilerini değerlendirme konusunda yaptıkları çalışmada teslimat güvenilirliği, tedarikçilerin karlılığı, tedarikçi ilişkileri, uygunluk kalitesi, tedarikçilerin esnekliği, içsel hizmet kalitesi, yeşil tasarım, yeşil satın alma, yeşil üretim, çevresel yönetim sistemi ve ISO 14000 sertifikaları kriterlerini kullanmışlardır. Awasthi vd. (2010) çevre dostu teknoloji ve malzeme kullanımı, yeşil pazar payı, yeşil ortaklıklar, yönetim taahhüdü, çevresel politikalara uyum, yeşil Ar-Ge, çalışanların çevresel konulardaki eğitimi, yalın süreç planlama, çevresel sertifikalar, kirlilik kontrolü kriterlerini kullanarak tedarikçi değerlendirme modeli geliştirmişlerdir. Büyüközkan ve Çiftçi (2012) ise otomobil endüstrisindeki bir işletmesinin tedarikçilerini kalite, maliyet, teslimat zamanı, esneklik, yeşil lojistik uygulamaları, yeşil operasyonel faaliyetler ve alternatif yeşil tedarik zinciri faaliyetleri kriterleri ile değerlendirmişlerdir.

Son y1llarda ise Tseng ve Chiu (2013) yaşam çevrim analizi, toplam kalite çevresel yönetimi, çevresel sertifikalar, çevresel üretim, yeşil satın alma, bilgi tabanlı çevresel yönetim sistemleri, yeşil ürünlerde Ar-Ge, tehlikeli ürün kullanımını kriterleri ile farklı bir yeşil tedarikçi değerlendirme modeli oluşturmuşlardır. Shen vd. (2013) tedarikçilerin yeşil performansını değerlendirmek için kaynak tüketimi, çevresel üretim, yeşil tasarım, yeşil imaj, çevresel yönetim sistemi, üst yönetim taahhüdü, çevre dostu teknoloji ve malzeme kullanımı, çalışanların çevresel eğitimi gibi bazı çevresel kriterleri kullanmışlardır. Govindan vd. (2013) tedarikçilerin sürdürülebilirliğinin ölçülmesinde çevresel, ekonomik ve sosyal kriterler belirlemişlerdir. Çevresel kriterler altında yeşil üretim, kaynak kullanımı, yeşil tasarım ve çevresel yönetim sistemi alt kriterleri kullanılmıştır. Tablo 1'de yukarıda bahsedilen çalışmalar özet bir şekilde sunulmuştur.

Tablo 1. Yeşil Tedarikçi Değerlendirme Kriterleri

\begin{tabular}{|lll|}
\hline Yazarlar (Yıl) & Sektör & Kriterler \\
\hline Noci (1997) & Otomobil & $\begin{array}{l}\text { Yeşil yetkinlikler, Yeşil imaj, Çevresel verimlilik, Yaşam } \\
\text { çevrim maliyeti }\end{array}$ \\
\hline Humpreys vd. (2003) & Iletişim & $\begin{array}{l}\text { Çevre kirliliği, Üst yönetim desteği, Yeşil imaj, Çevresel } \\
\text { yönetim sistemi tasarım,, Çevresel yetkinlikler }\end{array}$ \\
\hline Chiou vd. (2008) & Elektronik & $\begin{array}{l}\text { Çevresel yetkinlikler, Çevresel yönetim sistemi, Çevresel } \\
\text { performans, Kurumsal sosyal sorumluluk }\end{array}$ \\
\hline Lee vd. (2009) & Elektronik & $\begin{array}{l}\text { Tedarikçi kalitesi, Teknoloji yeterliliği, Kirlilik kontrolü, } \\
\text { Çevresel yönetim sistemi, Yeşil ürünler, Çevresel } \\
\text { yetkinlikler }\end{array}$ \\
\hline $\begin{array}{lll}\text { Feyzioğlu ve } \\
\text { Büyüközkan (2010) }\end{array}$ & Beyaz eşya (elektronik) & $\begin{array}{l}\text { Ürün maliyeti, Ürün kalitesi, Hizmet performans1, Çevresel } \\
\text { performans }\end{array}$ \\
\hline Chen vd. (2010) & Elektronik & $\begin{array}{l}\text { Teslimat güvenilirliği, Tedarikçi karlılığ1, Tedarikçi } \\
\text { ilişkileri, Uygunluk kalitesi, Tedarikçilerin esnekliği, İçsel } \\
\text { hizmet kalitesi, Yeşil tasarım, Yeşil satın alma, Yeşil üretim, } \\
\text { Çevresel yönetim sistemi, ISO 14000 }\end{array}$ \\
\hline Awasthi vd. (2010) & & $\begin{array}{l}\text { Çevre dostu teknoloji ve malzeme kullanımı, Yeşil pazar } \\
\text { payl, Yeşil ortaklıklar, Yönetim desteği, Çevresel } \\
\text { politikalara uyum, Yeşil Ar-Ge, Çalışanların eğitimi, Yalın } \\
\text { süreç planlama, Çevresel sertifikalar, Kirlilik kontrolü }\end{array}$ \\
\hline
\end{tabular}




\begin{tabular}{|lll|}
\hline $\begin{array}{l}\text { Büyüközkan ve Çiftçi } \\
\text { (2012) }\end{array}$ & Otomobil & $\begin{array}{l}\text { Tedarikçi kalitesi, Maliyet, Teslimat zamanı, Esneklik, Yeşil } \\
\text { lojistik uygulamaları, Yeşil operasyonel faaliyetler }\end{array}$ \\
\hline Tseng ve Chiu (2013) & Elektrik-elektronik & $\begin{array}{l}\text { yaşam çevrim analizi, Toplam kalite çevresel yönetimi, } \\
\text { Çevresel sertifikalar, Çevresel üretim, Yeşil satın alma, Bilgi } \\
\text { tabanlı çevresel yönetim sistemleri, Yeşil ürünlerde Ar-Ge, } \\
\text { Tehlikeli ürün kullanımını }\end{array}$ \\
\hline Shen vd. (2013) & & $\begin{array}{l}\text { Kaynak tüketimi, Çevresel üretim, Yeşil tasarım, Yeşil imaj, } \\
\text { Çevresel yönetim sistemi, Üst yönetim taahhüdü, Çevre } \\
\text { dostu teknoloji ve malzeme kullanımı, Çalışanların çevresel } \\
\text { eğitimi }\end{array}$ \\
\hline Govindan vd. (2013) & Otomobil & $\begin{array}{l}\text { Yeşil üretim, Kaynak kullanımı, Yeşil tasarım, Çevresel } \\
\text { yönetim sistem }\end{array}$ \\
\hline
\end{tabular}

\subsection{Yeşil Tedarikçi Değerlendirme}

İşletmeler küresel ısınma, karbon ayak izi, yasal standartlar gibi çevresel kısıtlamalardan dolayı çevresel konulara daha fazla ilgi göstermeye başlamışlardır. Bu yüzden son yıllarda stratejik planlamalar yapılırken çevreyi ilgilendiren konular ilk sıralarda yerini almaktadır. İşletmelerin paydaşları tedarikçiler, müşteriler, finansal kurumlar, yasal düzenleyiciler, toplum, rakipler ve devlet organlarından gelen baskılar işletmeleri tedarikçi seçiminde ve değerlendirmesinde daha fazla çevresel olmaya zorlamaktadır. Bu durum hem işletmeleri hem de tedarikçilerini çevresel performanslarını artırmaya yönelik planlar yapmaya yönlendirmektedir (Akman, 2015). Bu yüzden akademisyenler ve araştırmacılar yeşil tedarikçilerin seçiminde ve değerlendirilmesinde işletmelere yardımcı olabilmek ve destek verebilmek maksadıyla bazı teknikler önermektedirler. Literatüre bakıldığında teknikler tek başına veya bütünleşik olarak birlikte kullanılmıştır (Govindan vd., 2015). Örneğin tek başına kullanılan teknikler AHP (Noci, 1997; Handfield vd., 2002), Bulanık AHP (Lu vd., 2007; Chiou vd., 2008), ANP (Hsu ve Hu, 2007), Bulanık ANP (Büyüközkan ve Çiftçi, 2011), Doğrulayıc1 Faktör Analizi (Chiou vd., 2011), Çok Amaçlı Genetik Algoritma (MOGA) (Yeh ve Chuang, 2011), Yapısal Eşitlik Modeli (Large ve Thomsen, 2011), Veri Zarflama Analizi (VZA) (Kumar ve Jain, 2010), Bulanık ViKOR (Awasthi ve Govindan, 2016) ve Bulanık TOPSIS (Awasthi vd., 2008; Govindan vd., 2013) teknikleridir. Bütünleşik kullanılan teknikler AHP ve Yapay Sinir Ağları (YSA) (Thongchattu ve Siripokapirom, 2010), AHP ve Genetik Algoritma (Yan, 2009), Veri Zarflama Analizi ve ANP (Kuo ve Lin, 2011), Bulanık Küme Teorisi ve Gri İlişkisel Analizi (GİA) (Chen vd., 2010), Gri Korelasyon Analizi ve AHP (Li vd Zhao, 2009), ANP ve TOPSíS (Akman ve Pişkin, 2013), Bulanık cortalama ve VIKOR (Akman, 2015) ve Bulanık AHP, Bulanık TOPSíS ve Bulanık Çok Amaçlı Doğrusal Programlama (Kannan vd., 2013) teknikleridir. Tablo 2'de yeşil tedarikçi seçimi ve değerlendirme konusunda yapılan çalışmalarda kullanılan ÇKKV teknikleri yer almaktadır.

Tablo 2. Yeşil Tedarikçi Değerlendirmede Kullanılan Yöntemler

\begin{tabular}{|ll|}
\hline Yöntem & Kullanıldığı Çalışmalar \\
\hline AHP & Noci (1997); Handfield vd. (2002) \\
\hline Bulanık AHP & Lu vd. (2007); Chiou vd. (2008); Lee vd. (2009) \\
\hline ANP & Hsu ve Hu (2007) \\
\hline Bulanık ANP & Büyüközkan ve Çiftçi (2011) \\
\hline Doğrulayıcı Faktör Analizi & Chiou vd. (2011) \\
\hline Çok Amaçlı Genetik Algoritma & Yeh ve Chuang (2011) \\
\hline Yapısal Eşitlik Modeli & Large ve Thomsen (2011) \\
\hline VZA & Kumar ve Jain (2010) \\
\hline Bulanık VİKOR & Awasthi ve Govindan (2016) \\
\hline Bulanık TOPSİS & Awasthi vd. (2008); Govindan vd. (2013) \\
\hline Bulanık GİA & Chen vd. (2010) \\
\hline AHP ve YSA & Thongchattu ve Siripokapirom (2010) \\
\hline AHP ve Genetik Algoritma & Yan (2009) \\
\hline AHP ve Gri Korelasyon Analizi & Li ve Zhao (2009) \\
\hline ANP ve TOPSİS & Akman ve Pişkin (2013) \\
\hline Bulanık AHP, Bulanık TOPSíS ve Bulanık Doğrusal Prog. & Kannan vd. (2013) \\
\hline
\end{tabular}

\section{Metodoloji}

Rekabetin artması ile birlikte işletmeler tedarik zinciri stratejilerini yeniden gözden geçirmektedirler. Toplumun beklentilerinin değişmesi, doğal kaynakların her geçen gün azalması, firmalar arası ekonomik işbirliklerinin artması işletmeleri daha çevresel düşünmeye zorlamaktadır. Bu da tedarik zincirinin etkin yönetilmesi ile mümkün olmaktadır (Vachon ve Klassen, 2005). Etkin tedarik zinciri yönetimi tersine lojistik, yeşil tedarik zinciri ve sürdürülebilir tedarik 
zinciri yönetiminin birlikte ele alınması ile başarıyı getirmektedir. İşletmelerin sürdürülebilir hedeflerine ulaşması çevresel faaliyetlere önem veren en uygun tedarikçiler ile mümkün olmaktadır. Ancak günümüz iş dünyasının karmaşıklığı, alternatiflerin fazlalığı, kriterlerin çok olması yeşil tedarikçi seçimi sürecini etkilemektedir. Böylesi belirsiz ortamlar altında işletmelere bulanık çok kriterli karar verme tekniklerinin kullanımı önerilmektedir.

Çalışmada yeşil tedarikçi geliştirme programlarının değerlendirilmesi süreci üç adımdan oluşmaktadır. İlk olarak literatürde yer alan çalışmalar incelenerek ve uygulamanın yapılacağı işletmenin uzmanlarına danışılarak nominal grup tekniği yardımıyla hangi kriterlerin ve alternatif programların kullanılması gerektiği belirlenmiştir. Ardından belirsiz koşullar altında tedarikçilerin çevresel performansını geliştirmeye yönelik alternatif programlar bulanık MOORA yöntemi ile sıralanmıştır. Son olarak ise duyarlılık analizi ile kriterlerin ağırlıkları değiştirilerek programların sıralamaya olan etkisi değerlendirilmiştir.

\subsection{Yeşil Tedarikçi Geliştirme Programları ve Kriterlerin Seçimi}

Yeşil tedarikçi geliştirme programlarının değerlendirilmesi için uygulamanın yapıldığı elektronik ev aletleri imalatçısında çalışan uzmanlar yardımıyla nominal grup tekniği ile bazı kriterler belirlenmiştir. Öncelikle uzmanlardan tedarikçi geliştirmede önemsedikleri kriterleri yazmaları istenmiştir. Daha sonra literatürde yer alan diğer kriterler uzmanların görüşlerine sunulmuştur. Bu sayede işletmenin amacına ve değerlerine uygun görülen kriterler de değerlendirmeye alınmıştır. Değerlendirmenin sonunda her uzmandan kriterleri puanlamaları istenmiştir. Süreç sonunda Tablo 3'te görüldüğü üzere en yüksek puanı alan 11 kriter yeşil tedarikçi geliştirme programlarının seçimi üzerinde etkisinin olduğu ortaya çıkmıştır. Diğer taraftan işletme yöneticileri 4 adet yeşil tedarikçi geliştirme programı üzerinde çalışmalar yapmakta ve bunlardan en uygun olan(lar)ını tedarikçilerine uygulamak istemektedirler.

Tablo 3. Yeşil Tedarikçi Geliştirme Programları Değerlendirme Kriterleri

\begin{tabular}{|c|c|c|c|}
\hline $\begin{array}{l}\text { Kriter } \\
\text { Tipi }\end{array}$ & Kriterler & Tanımlama & Yazarlar \\
\hline $\mathbf{M}$ & Maliyet (K1) & $\begin{array}{l}\text { Ürün maliyeti: Üretim, bakım ve taşımadan } \\
\text { kaynaklanan üretim maliyeti } \\
\text { Sipariş verme maliyeti: Birim değişken ve } \\
\text { sabit sipariş maliyetleri } \\
\text { Lojistik maliyeti: Birim değişken ve sabit } \\
\text { ulaştırma maliyetleri }\end{array}$ & $\begin{array}{l}\text { Zhang vd. (2003); Yeh ve } \\
\text { Chuang (2011); Kuo vd. } \\
\text { (2010); }\end{array}$ \\
\hline $\mathbf{M}$ & $\begin{array}{l}\text { İmalat Çıktıs1 } \\
\text { (K2) }\end{array}$ & $\begin{array}{l}\text { İmalat boyunca çevreye salınan kirli gaz, } \\
\text { su, katı atıkların, zararlı maddelerin ve } \\
\text { gürültünün miktarı }\end{array}$ & $\begin{array}{l}\text { Feyzioğlu ve Büyüközkan } \\
\text { (2010); Chiou vd. (2011); } \\
\text { Large ve Thomsen (2011); } \\
\text { Govindan vd. (2013) }\end{array}$ \\
\hline $\mathbf{M}$ & $\begin{array}{l}\text { Kaynak } \\
\text { Kullanımı (K3) } \\
\end{array}$ & $\begin{array}{l}\text { İmalat sürecinde hammadde, enerji ve } \\
\text { suyun tüketim miktarı }\end{array}$ & $\begin{array}{l}\text { Noci (1997); Hvefield vd. } \\
(2002)\end{array}$ \\
\hline $\mathbf{F}$ & Kalite (K4) & $\begin{array}{l}\text { Kalite güvence: Sertifikalar ile kalite } \\
\text { güvencenin kazanılmas1 } \\
\text { Red oranı: Kalite kontrol tarafından tespit } \\
\text { edilip reddedilen gelen malzeme sayıs1 }\end{array}$ & $\begin{array}{l}\text { Zhang vd., (2003); Yang ve } \\
\text { Wu (2008); Lee vd. (2009); } \\
\text { Kuo vd. (2010); Yan (2009); } \\
\text { Grisi vd. (2010) }\end{array}$ \\
\hline $\mathbf{F}$ & Teslimat (K5) & $\begin{array}{l}\text { Teslim zamanı: Malzeme sipariş ile teslim } \\
\text { etme arasında geçen süre } \\
\text { Zamanında teslimat: Önceden belirlenmiş } \\
\text { teslimat çizelgesine uyma yeteneği }\end{array}$ & $\begin{array}{l}\text { Yang ve Wu (2008); Yan } \\
\text { (2009); Kuo vd. (2010); } \\
\text { Feyzioğlu ve Büyüközkan } \\
(2010)\end{array}$ \\
\hline $\mathbf{F}$ & Teknoloji (K6) & $\begin{array}{l}\text { Teknoloji seviyesi: Tedarikçilerin talepleri } \\
\text { karş1lamada kullanıkları teknoloji } \\
\text { Ar-Ge: Tedarikçilerin talepleri karşılamada } \\
\text { Ar-Ge'yi kullanma becerisi }\end{array}$ & $\begin{array}{l}\text { Li ve Zhao (2009); Lee vd. } \\
\text { (2009); Büyüközkan ve Çifçi } \\
\text { (2010); Awasthi vd. (2010) }\end{array}$ \\
\hline $\mathbf{F}$ & $\begin{array}{l}\text { Çevresel } \\
\text { Tasarım (K7) }\end{array}$ & $\begin{array}{l}\text { Enerji tasarrufu, ürünlerin tekrar kullanımı, } \\
\text { geri dönüşümü amacıyla yapılan ürün } \\
\text { tasarımı ve tehlikeli malzemelerin } \\
\text { kullanımını azaltmak veya kullanımından } \\
\text { kaçınmak için yapılan ürün tasarımı }\end{array}$ & $\begin{array}{l}\text { Humphreys vd. (2006); } \\
\text { Awasthi vd. (2010); Govindan } \\
\text { vd. (2013) }\end{array}$ \\
\hline $\mathbf{F}$ & $\begin{array}{l}\text { Çevresel } \\
\text { Yönetim Sistemi } \\
(\mathrm{K} 8)\end{array}$ & $\begin{array}{l}\text { ISO } 14000 \text { gibi çevresel sertifikalar, } \\
\text { çevresel politikalar, çevresel hedeflerin } \\
\text { planlanmas1, çevresel faaliyetlerin kontrolü }\end{array}$ & $\begin{array}{l}\text { Zhang vd., (2003); Humphreys } \\
\text { vd. (2006); Chiou vd. (2008); } \\
\text { Li ve Zhao (2009); Yan } \\
\text { (2009); Kuo vd. (2010); Lee } \\
\text { vd. (2009); Chen vd. (2010); } \\
\text { Grisi vd. (2010) }\end{array}$ \\
\hline $\mathbf{F}$ & Yeşil İmaj (K9) & $\begin{array}{l}\text { Çevreyi korumadaki gayret ve başarı } \\
\text { ölçümü }\end{array}$ & $\begin{array}{l}\text { Lee vd. (2009); Humphreys } \\
\text { vd. (2006); Grisi vd. (2010) }\end{array}$ \\
\hline $\mathbf{F}$ & $\begin{array}{l}\text { Yeşil Satın Alma } \\
\text { (K10) }\end{array}$ & Çevre dostu hammadde satın alınması & Chen vd. (2010) \\
\hline $\mathbf{F}$ & Tersine Lojistik & Ürün kullanımı sona erdikten sonra yeniden & Handfield vd. (2002); Lee vd. \\
\hline
\end{tabular}




(K11) $\quad$ imalat ve kullanımı

Tablo 3'e bakıldığında tedarikçi geliştirme programları seçiminde K1 - K3 kriterleri maliyet yapılı olup, K4 - K11 kriterleri fayda yapısındadır.

Nominal grup tekniği ile kriterlerin önem ağırlıklarının belirlenmesi sürecinde ve alternatiflerin seçiminde bulanıklığın olmasından ve kesin yargıların eksikliğinden dolayı Tablo 4'te yer alan dilsel değişkenlerden yararlanılmıştır. Özellikle çevreyi ilgilendiren karar verme süreçlerin sıklıkla görülen kesin olmayan (belirsiz) durumlar altında yöneticiler kesin yargılar yerine çok yüksek, orta, çok düşük gibi bulanık yargıları kullanmayı tercih etmektedirler (Awasthi ve Govindan, 2016). Kriterlerin önem ağrllıkları belirlendikten sonra uzmanlar alternatiflerin tercihi için ise benzer değişkenleri kullanmaktadırlar. Bu değişkenler üçgensel bulanık sayılar ile en kötü, ortalama, en iyi değerler ile ifade edilmektedir.

Tablo 4. Kriterler ve Alternatifler için Dilsel Değişkenler

\begin{tabular}{|ll|}
\hline Dilsel Değişken & Bulanık sayılar \\
\hline Çok düşük $(C ̧ D)$ & $(1,1,3)$ \\
\hline Düşük $(\mathrm{D})$ & $(1,3,5)$ \\
\hline Orta $(\mathrm{O})$ & $(3,5,7)$ \\
\hline Yüksek $(Y)$ & $(5,7,9)$ \\
\hline Çok yüksek $(C ̧ Y)$ & $(7,9,9)$ \\
\hline
\end{tabular}

Kaynak: (Awasthi ve Govindan, 2016)

\subsection{Bulanık MOORA Yöntemi}

İşletmenin tedarikçileri için en uygun tedarikçi geliştirme programının seçimi için çok kriterli karar verme tekniklerinden biri olan MOORA yönteminden yararlanılmıştır. Çok amaçlı optimizasyon yöntemi olan ve oransal analize dayalı MOORA (Multi-objective Optimization on the Basis of Ratio Analysis) yöntemi çeşitli karar problemlerinde kullanılmakta ve karar vericilere alternatif çözümler sunmaktadır (Brauers, 2004). Bulanık küme teorisi ile birleştirilen bulanık MOORA yöntemi ise ilk kez Brauers ve Zavadskas (2006) tarafından kamuda özelleştirme konusunda yapmış oldukları çalışmada kullanılmıştır. MOORA yöntemi diğer çok kriterli karar verme yöntemleri kadar eski olmamasına rağmen literatürde pek çok çalışmada kendisine yer bulmuş olup oran yöntemi, referans noktası yöntemi ve tam çarpımsal form olmak üzere üç farklı yaklaşımdan oluşmaktadır. Brauers ve Zavadskas (2012)'a göre MOORA yöntemi bazı çok kriterli karar verme yaklaşımlarından farklılaşmaktadır. Örneğin bu yöntemin AHP, TOPSIS, ELECTRE, VIKOR ve PROMETHEE yaklaşımlarına göre hesaplama zamanı oldukça az ve matematiksel işlemleri de kısa ve basittir. Diğer taraftan güvenilirliği yüksek olup veri inceleme açısından karar vericiye kolaylıklar sağlamaktadır.

Son yıllarda literatürde MOORA ve bulanık MOORA yöntemleri kullanılarak yapılan çalışmalar bulunmaktadır. Örneğin Balezentis (2011) tarımsal ürünlerin verimliliğini tahmin etmede, Archana ve Sujatha (2012) toplumun istedikleri an ve yerde internet hizmeti alabilmesi için kablosuz internet hizmeti veren kurumlar seçiminde, Streimikiene vd. (2012) en uygun enerji üretim teknolojisi seçiminde, Karande ve Chakraborty (2012) işletmeler için en uygun KKP yazılımı seçiminde, benzer bir şekilde Vatansever ve Uluköy (2013) Türk firmalar için Kurumsal Kaynak Planlaması (KKP) yazılımı seçiminde, Yıldırım ve Önay (2013) bulut teknolojisi hizmeti sağlayan firmaların sıralanmasında, Tepe ve Görener (2014) personel seçimi probleminde, Özçelik vd. (2014) Kayseri’de özel eğitim ve rehabilitasyon merkezi yeri seçiminde, Aktepe ve Ersöz (2014) en uygun depo yeri seçiminde, Uyguntürk (2015) mevcut ve potansiyel müşteriler açısından en uygun internet şubesine sahip bankaların seçiminde, Akkaya vd. (2015) endüstri mühendisliği bölümünü bitiren öğrencilerin hangi sektörde çalışmak istediklerini belirlemede MOORA ve bulanık MOORA yaklaşımlarını kullanmışlardır.

Yöntemin adımlarına geçmeden önce kriterlerin ve alternatif programların bulanık değerlerini bulanık olmayan (crisp) sayılara dönüştürmek gerekmektedir. Örneğin $\tilde{a}=\left(a_{1}, a_{2}, a_{3}\right)$ bulanık sayısının bulanık olmayan sayılara dönüştürmede aşağıdaki formül kullanılacaktır.

$$
a=\frac{a_{1}+4 a_{2}+a_{3}}{6}
$$

Yukarıdaki işlem karar vericilerin kriterleri değerlendirme aşamasında üçgensel bulanık sayılar ile ifade edilen kriter ağırlıklarını bulanık olmayan sayılara dönüştürme sırasında kullanılmaktadır.

Bulanık MOORA yönteminin adımları sırasıyla şu şekildedir (Vatansever ve Uluköy, 2013; Akkaya vd., 2015).

1. Adım: Üçgensel bulanık sayılardan oluşan karar matrisi oluşturulur. 


$$
\tilde{X}=\left[\begin{array}{cccc}
{\left[x_{11}^{l}, x_{11}^{m}, x_{11}^{u}\right]} & {\left[x_{12}^{l}, x_{12}^{m}, x_{12}^{u}\right]} & \ldots \ldots & {\left[x_{1 m}^{l}, x_{1 m}^{m}, x_{1 m}^{u}\right]} \\
\ldots \ldots & \ldots \ldots & \ldots \ldots & \ldots \ldots \\
\ldots \ldots & \ldots \ldots & \ldots \ldots & \ldots \ldots \\
{\left[x_{n 1}^{l}, x_{n 1}^{m}, x_{n 1}^{u}\right]} & {\left[x_{n 2}^{l}, x_{n 2}^{m}, x_{n 2}^{u}\right]} & \ldots \ldots & {\left[x_{n m}^{l}, x_{n m}^{m}, x_{n m}^{u}\right.}
\end{array}\right]
$$

Bu karar matrisine göre $\mathrm{m}$ alternatifleri, $\mathrm{n}$ kriterleri, xnm n. kritere göre m. alternatifin aldığı üçgensel küçük, orta ve büyük bulanık değerlerini göstermektedir.

2. Adım: Oluşturulan karar matrisi bu adımda normalleştirilmektedir. Normalleştirme süreci matris formunun daha doğru olmasını ve ikili karşılaştırmaların daha iyi yapılabilmesini sağlamaktadır (Balezentis vd., 2012). Her üç bulanık sayının normalleştirilmesi (r) aşağıdaki denklem ile yapılmaktadır.

$$
\begin{aligned}
& r_{i j}^{l}=\frac{x_{i j}^{l}}{\sqrt{\sum_{i=1}^{n}\left[\left(x_{i j}^{l}\right)^{2}+\left(x_{i j}^{m}\right)^{2}+\left(x_{i j}^{u}\right)^{2}\right]}} \\
& r_{i j}^{m}=\frac{x_{i j}^{m}}{\sqrt{\sum_{i=1}^{n}\left[\left(x_{i j}^{l}\right)^{2}+\left(x_{i j}^{m}\right)^{2}+\left(x_{i j}^{u}\right)^{2}\right]}} \\
& r_{i j}^{u}=\frac{x_{i j}^{u}}{\sqrt{\sum_{i=1}^{n}\left[\left(x_{i j}^{l}\right)^{2}+\left(x_{i j}^{m}\right)^{2}+\left(x_{i j}^{u}\right)^{2}\right]}}
\end{aligned}
$$

3. Adım: Denklem (1) ile elde edilen ağırlıklar yardımıyla ağırlıklı normalize bulanık karar matrisi oluşturulur.

$$
\begin{aligned}
& v_{i j}^{l}=W_{j} r_{i j}^{l} \\
& v_{i j}^{m}=W_{j} r_{i j}^{m} \\
& v_{i j}^{u}=W_{j} r_{i j}^{u}
\end{aligned}
$$

4. Adım: Bu adımda fayda (yarar) ve maliyet (zarar) kriterleri açısında normalize edilmiş performans değerleri (S) bulunmaktadır. Fayda kriterleri için üçlü bulanık sayılar ayrı ayrı;

$$
\begin{aligned}
& S_{i}^{+l}=\sum_{j=1}^{m} v_{i j}^{l} \mid j \in J^{e n b} \\
& S_{i}^{+m}=\sum_{j=1}^{m} v_{i j}^{m} \mid j \in J^{e n b} \\
& S_{i}^{+u}=\sum_{j=1}^{m} v_{i j}^{u} \mid j \in J^{e n b}
\end{aligned}
$$

Maliyet kriterleri için üçlü bulanık sayılar ayrı ayrı;

$$
\begin{aligned}
& S_{i}^{-l}=\sum_{j=1}^{m} v_{i j}^{l} \mid j \in J^{e n k} \\
& S_{i}^{-m}=\sum_{j=1}^{m} v_{i j}^{m} \mid j \in J^{e n k} \\
& S_{i}^{-u}=\sum_{j=1}^{m} v_{i j}^{u} \mid j \in J^{e n k}
\end{aligned}
$$

hesaplanmaktadir.

5. Adım: Normalize edilmiş performans değerleri hâlen bulanık sayılardır. Bu adımda değerler vertex yöntemi kullanılarak bulanık olmayan performans değerlerine dönüştürülmektedir.

$$
S_{i}=\sqrt{\frac{1}{3}\left[\left(s_{i}^{+l}-s_{i}^{-l}\right)^{2}+\left(s_{i}^{+m}-s_{i}^{-m}\right)^{2}+\left(s_{i}^{+n}-s_{i}^{-n}\right)^{2}\right]}
$$

6. Adım: Ortaya çıkan en yüksek performans değerlerine göre alternatifler sıralanmaktadır. En yüksek performans değerine sahip alternatif tercih edilmektedir.

\subsection{Duyarlılı Analizi}


Analiz neticesinde çıkan sonuçlar, karar vericilerin öznel yargılarına ve kriterlerin öncelikli tercihlerine göre değişim gösterebilmektedir. Bundan dolayı farklı senaryolar veya durumlar altında sonuçların nasıl değiştiğini gözlemlemek için duyarlılık (etkinlik) analizi yapılması gerekmektedir. Bu analiz, kriterlerin önemi hakkında bilgi verirken belirsizlikten bahsedildiği durumlarda karar vericiler için oldukça yararlı olmaktadır. Çalışmada bulanık MOORA yöntemi ile elde edilen sonuçlar üzerinde kriterlerin önem ağırlıklarının etkinliğini test etmek amacıyla 15 farklı durum incelenmiştir.

$\mathrm{Bu}$ durumlardan 11'inde sırasıyla her bir tek kriterin ağırlığı en yüksek, geri kalanları ise 0 olacak şekilde düzenlenmiştir. Daha sonra 12. durumda bütün kriterlerin ağırlıkları toplamı 1'e tamamlanacak şekilde eşit, 13. durumda sadece maliyet yapılı kriterlerin kullanıldı̆̆ı ve ağırlıkları eşit, 14. durumda sadece fayda yapılı kriterlerin kullanıldığı ve ağırlıkları eşit, 15. durumda bütün kriterlerin ağırlıkları 1'e tamamlanacak şekilde rastgele sayılar verilerek denemeler yapılmıştır.

\section{Uygulama}

Günümüzde otomotiv, beyaz eşya, gıda, ağır metal, tekstil gibi büyük işletmeler yeşil üretim, uygun çalışma koşulları, ISO 14000 sertifikaları gibi tedarik zinciri yönetiminde sürdürülebilir faaliyetlerini iyileştirmeye çalışmaktadırlar. Bu kapsamda çalışmada, beyaz eşya sektöründe faaliyet gösteren elektronik ev aletleri imalatçısının tedarikçileri için kendilerini geliştirmeleri yönünde program seçimi yapılmıştır. Uygulamanın yapıldığı bu işletme pek çok tedarikçi ile çalışmaktadır. Fakat işletme, çevresel ve ekonomik performansını artırabilmek, ürünlerinde kaliteyi koruyabilmek, artan müşteri baskılarına cevap verebilmek, tehlikeli atık ve karbon salınım miktarını azaltabilmek amacıyla yeşil tedarikçiler ile güçlü stratejik ortaklıklar kurmak ve onların çevresel performanslarını artırmak istemektedir.

İşletmenin tedarikçilerinin gelişimleri açısından destek olmaya çalışan Satınalma Yardımcı Sanayi Geliştirme Bölümü bulunmakta olup tedarikçilerinin altyapılarını iyileştirmelerine destek olmak için projeler geliştirmektedir. Bu çalışmalar hem firmaya rekabet açısından avantaj sağlamakta hem de maliyetler düşürülürken kalitenin arttırılmasına destek olmaktadır. Ayrıca "kazanç paylaşım” modelli verimlilik projeleri hayata geçirilerek tedarikçilerin kaliteleri artması amaçlanmaktadır. İşletme, yeşil tedarikçiler gelişmesi için (A1) "sertifikalandırma”, (A2) “Ar-Ge desteği””, (A3) "tedarikçi toplantıları" ve (A4) "uzman desteği ve teknik eğitim" programları ile ilgilenmektedir.

İşletme, tedarikçilerine ISO 14001, 9001 gibi çevresel ve kalite yönetim sertifikaları kazandırma konusunda baskı kurması gerekmektedir. Düzenlemelere, yasalara ve standartlara uyum ile alınan cezalara azalacak ve tedarik zinciri içerisindeki ortakların yeşil imajı ve başarısı artmış olacaktır. Diğer taraftan enerji ve hammadde tüketiminde tasarruf sağlanması süreçlerde yeşil üretim faaliyetlerinin gerçekleştiğini göstermektedir. Bu da düzenli Ar-Ge desteği ile mümkün olması beklenmektedir. Bilindiği üzere doğal kaynaklar sürekli olarak azalmaktadır. Tedarikçilerin bu konuya dikkat etmesi bazı çevresel yararlar sağlarken enerji tüketim maliyetlerinde azalma işletmeye ekonomik fayda sağlayacaktır. İşletme, tedarikçi performansı iyileştirmesinde bazı spesifik konularda özel araştırmalar yapmakta ve tedarikçiler ile sıklıkla toplantılar organize etmektedir. Bu toplantılarda sektörün gelişimi, küresel pazarın durumu, yeni ürün projeleri, maliyet rekabetçiliği ve tedarikçi geliştirme programları üzerinde durulmaktadır. Üst yönetim desteği ve çalışanlara teknik eğitimlerin verilmesi yeşil tedarikçi gelişmi için önemli faaliyetlerden biri durumundadır. Uygulamada Satın Alma, Tedarik Zinciri ve Üretim Planlama birimlerinden sorumlu üç karar verici Tablo 3'te yer alan yeşil tedarikçi geliştirme programları değerlendirme kriterleri ile programların seçimini ve değerlendirmesini yapmaktadırlar. Kriterlerin ve alternatif programların değerlendirmesi için Tablo 4'de ki dilsel değişkenlerden yararlanılmıştır.

\subsection{Bulanık MOORA Uygulamast}

Bulanık MOORA yöntemi ile uygulamaya başlamadan önce her hangi bir kriterin toplam bulanık değeri $\left(\tilde{w}_{i}\right)$ hesaplanması gerekmektedir. Buna göre her bir karar verici kendi deneyimi ve bilgisi gereği dilsel değişkenler kullanarak kriterleri puanlandırmaktadır. Örneğin $\mathrm{K}_{1}$ kriteri KV1 "Çok Düşük", KV2 "Düşük" ve KV3 ise "Yüksek" şeklinde puanlandırmaktadır. $\mathrm{K}_{1}$ 'in toplam bulanık performans değeri; $\widetilde{w}_{1}=\left\{\min (1,1,3), \frac{1}{3}(1+3+5), \max (3,5,7)\right\}=(1,3,7)$ olmaktadır. Daha sonra $\left(\tilde{w}_{i}\right)$ bulanık değeri denklem (1) yardımıyla bulanık olmayan $\left(w_{i}\right)$ değerine dönüştürülmelidir. $\mathrm{K}_{1}$ kriterinin bulanık olmayan değeri $w_{j}=\frac{1+(4 * 3)+7}{6}=3.333$ çıkmaktadır. Diğer kalan kriterler de benzer şekilde hesaplanmaktadır. Tablo 5'te 11 kriterin önem ağırlıkları hesaplanarak verilmiştir.

Tablo 5. Kriterlerin Dilsel İfadeleri ve Ağırlıkları

\begin{tabular}{|c|c|c|c|c|c|c|}
\hline \multirow[t]{2}{*}{ Kriterler } & \multicolumn{3}{|c|}{ Karar vericiler } & \multirow{2}{*}{$\begin{array}{l}\text { Toplam } \\
\text { bulanık } \\
\text { sayılar }\end{array}$} & \multirow{2}{*}{$\begin{array}{c}\text { Bulanık } \\
\text { olmayan } \\
\text { sayılar }\end{array}$} & \multirow{2}{*}{$\begin{array}{c}\text { Normalize edilmiş } \\
\text { bulanık olmayan } \\
\text { sayılar }\end{array}$} \\
\hline & KV1 & KV2 & KV3 & & & \\
\hline $\mathbf{K}_{1}$ & ÇD & $\mathrm{D}$ & $\mathrm{O}$ & $(1,3,7)$ & 3.333 & 0.0632 \\
\hline $\mathbf{K}_{2}$ & $\mathrm{D}$ & $\mathrm{O}$ & $\mathrm{Y}$ & $(1,5,9)$ & 5.000 & 0.0947 \\
\hline $\mathrm{K}_{3}$ & ÇD & ÇD & $\mathrm{D}$ & $(1,1.667,5)$ & 2.111 & 0.0400 \\
\hline
\end{tabular}


Sisman, B. / Journal of Yasar University, 2016, 11/44, 302-315

\begin{tabular}{lllllll}
\hline $\mathbf{K}_{\mathbf{4}}$ & $\mathrm{D}$ & $\mathrm{O}$ & $\mathrm{D}$ & $(1,1.667,7)$ & 2.445 & 0.0463 \\
$\mathbf{K}_{\mathbf{5}}$ & ÇY & O & D & $(1,5.667,9)$ & 5.445 & 0.1032 \\
$\mathbf{K}_{\mathbf{6}}$ & $\mathrm{O}$ & $\mathrm{D}$ & $\mathrm{Y}$ & $(1,5,9)$ & 5.000 & 0.0947 \\
$\mathbf{K}_{\mathbf{7}}$ & $\mathrm{O}$ & $\mathrm{O}$ & $\mathrm{Y}$ & $(3,5.667,9)$ & 5.778 & 0.1095 \\
$\mathbf{K}_{\mathbf{8}}$ & $\mathrm{D}$ & $\mathrm{O}$ & ÇD & $(1,3,7)$ & 3.333 & 0.0632 \\
$\mathbf{K}_{\mathbf{9}}$ & ÇY & ÇY & Y & $(5,8.333,9)$ & 7.889 & 0.1495 \\
$\mathbf{K}_{\mathbf{1 0}}$ & Y & Y & ÇY & $(5,7.667,9)$ & 7.445 & 0.1411 \\
$\mathbf{K}_{\mathbf{1 1}}$ & O & O & O & $(3,5,7)$ & 5.000 & 0.0947 \\
\hline
\end{tabular}

Tablo 6'da karar vericiler tarafından dört alternatif yeşil tedarikçi değerlendirme programları için değerlendirmeleri verilmektedir.

Tablo 6. Alternatif Programların Dilsel İfadeleri

\begin{tabular}{|c|c|c|c|c|c|c|c|c|c|c|c|c|}
\hline \multirow{2}{*}{ Kriterler } & \multicolumn{3}{|c|}{ A1 } & \multicolumn{3}{|c|}{$\mathbf{A 2}$} & \multicolumn{3}{|c|}{$\mathbf{A 3}$} & \multicolumn{3}{|c|}{ A4 } \\
\hline & KV1 & KV2 & KV3 & KV1 & KV2 & KV3 & KV1 & KV2 & KV3 & KV1 & KV2 & KV3 \\
\hline $\mathbf{K}_{1}$ & $\mathrm{D}$ & ÇD & ÇD & $\mathrm{Y}$ & $\mathrm{D}$ & ÇD & $\mathrm{Y}$ & $\mathrm{Y}$ & ÇY & ÇD & ÇD & $\mathrm{O}$ \\
\hline $\mathbf{K}_{2}$ & D & $\mathrm{O}$ & $\mathrm{O}$ & Y & Y & D & ÇY & ÇY & Y & Y & $\mathrm{O}$ & ÇD \\
\hline $\mathbf{K}_{3}$ & $\mathrm{O}$ & $\mathrm{O}$ & $\mathrm{Y}$ & ÇY & Y & ÇD & D & $\mathrm{O}$ & Y & ÇD & ÇD & $\mathrm{O}$ \\
\hline $\mathbf{K}_{4}$ & Y & ÇY & ÇY & Y & Y & ÇD & ÇD & $\mathrm{O}$ & $\mathrm{O}$ & Y & Y & $\mathrm{O}$ \\
\hline $\mathrm{K}_{5}$ & ÇD & D & $\mathrm{O}$ & $\mathrm{D}$ & $\mathrm{O}$ & D & $\mathrm{O}$ & $\mathrm{O}$ & ÇY & ÇD & $\mathrm{Y}$ & ÇD \\
\hline$K_{6}$ & D & Y & $\mathrm{O}$ & Y & ÇD & $\mathrm{O}$ & $\mathrm{D}$ & ÇD & $\mathrm{Y}$ & $\mathrm{O}$ & $\mathrm{Y}$ & $\mathrm{Y}$ \\
\hline $\mathbf{K}_{7}$ & ÇD & Y & ÇY & D & $\mathrm{Y}$ & ÇY & ÇD & $\mathrm{O}$ & $\mathrm{Y}$ & ÇD & ÇD & ÇD \\
\hline $\mathbf{K}_{8}$ & $\mathrm{Y}$ & $\mathrm{O}$ & $\mathrm{Y}$ & $\mathrm{O}$ & ÇY & $\mathrm{O}$ & $\mathrm{Y}$ & ÇY & D & CDD & CD & Y \\
\hline $\mathbf{K}_{\mathbf{9}}$ & ÇY & Y & $\mathrm{Y}$ & $\mathrm{O}$ & $\mathrm{O}$ & D & ÇD & $\mathrm{O}$ & D & D & $\mathrm{O}$ & $\mathrm{Y}$ \\
\hline$K_{10}$ & $\mathrm{Y}$ & D & $\mathrm{O}$ & $\mathrm{D}$ & Y & ÇY & D & D & $\mathrm{O}$ & ÇD & $\mathrm{Y}$ & $\mathrm{O}$ \\
\hline$K_{11}$ & $\mathrm{O}$ & $\mathrm{O}$ & $\mathrm{Y}$ & $\mathrm{O}$ & ÇD & $\mathrm{D}$ & $\mathrm{Y}$ & $\mathrm{Y}$ & $\mathrm{O}$ & $\mathrm{D}$ & $\mathrm{D}$ & $\mathrm{O}$ \\
\hline
\end{tabular}

Tablo 6'da ki alternatif programlar için verilen dilsel ifadeler bulanık üçgensel sayılara dönüştürülmüş ve daha sonra kriterler için uygulanan toplam bulanık sayı oluşturma işlemi burada tekrar yapılmıştır. Bulanık MOORA yönetiminin birinci adımında Tablo 7'de alternatif programlar için bulanık karar matrisi oluşturulmuştur.

Tablo 7. Alternatif Programların Değerlendirilmesi İçin Bulanık Karar Matrisi

\begin{tabular}{lllll}
\hline Kriterler & \multicolumn{1}{c}{$\mathbf{A 1}$} & \multicolumn{1}{c}{$\mathbf{A 2}$} & \multicolumn{1}{c}{$\mathbf{A 3}$} & \multicolumn{1}{c}{$\mathbf{A 4}$} \\
\hline $\mathbf{K}_{\mathbf{1}}$ & $(1,1.667,5)$ & $(1,3.667,9)$ & $(5,7.667,9)$ & $(1,2.333,7)$ \\
$\mathbf{K}_{\mathbf{2}}$ & $(1,4.333,7)$ & $(1,5.667,9)$ & $(5,8.333,9)$ & $(1,4.333,9)$ \\
$\mathbf{K}_{\mathbf{3}}$ & $(3,5.667,9)$ & $(1,5.667,9)$ & $(1,5,9)$ & $(1,2.333,7)$ \\
$\mathbf{K}_{\mathbf{4}}$ & $(5,8.333,9)$ & $(1,5,9)$ & $(1,3.667,7)$ & $(3,6.333,9)$ \\
$\mathbf{K}_{\mathbf{5}}$ & $(1,3,7)$ & $(1,4.333,7)$ & $(3,6.333,9)$ & $(1,3,9)$ \\
$\mathbf{K}_{\mathbf{6}}$ & $(1,5,9)$ & $(1,4.333,9)$ & $(1,3.667,9)$ & $(3,6.333,9)$ \\
$\mathbf{K}_{\mathbf{7}}$ & $(1,5.667,9)$ & $(1,6.333,9)$ & $(1,4.333,9)$ & $(1,1,3)$ \\
$\mathbf{K}_{\mathbf{8}}$ & $(3,6.333,9)$ & $(3,6.333,9)$ & $(1,6.333,9)$ & $(1,3,9)$ \\
$\mathbf{K}_{\mathbf{9}}$ & $(5,7.667,9)$ & $(1,4.333,7)$ & $(1,3,7)$ & $(1,5,9)$ \\
$\mathbf{K}_{\mathbf{1 0}}$ & $(1,5,9)$ & $(1,6.333,9)$ & $(1,3.667,7)$ & $(1,4.333,9)$ \\
$\mathbf{K}_{\mathbf{1 1}}$ & $(3,5.667,9)$ & $(1,3,7)$ & $(3,6.333,9)$ & $(1,3.667,7)$ \\
\hline
\end{tabular}

Bulanık karar matrisi oluşturulduktan sonra ikinci adımda denklem (3), (4) ve (5) yardımı ile normalizasyon yapılmış ve Tablo 8'de normalize bulanık karar matrisi oluşturulmuştur.

Tablo 8. Normalize Edilmiş Bulanık Karar Matrisi

\begin{tabular}{lcccc}
\hline Kriterler & $\mathbf{A 1}$ & $\mathbf{A 2}$ & $\mathbf{A 3}$ & $\mathbf{A 4}$ \\
\hline $\mathbf{K}_{\mathbf{1}}$ & $(0.054,0.090,0.269)$ & $(0.054,0.198,0.485)$ & $(0.269,0.413,0.485)$ & $(0.054,0.126,0.377)$ \\
$\mathbf{K}_{\mathbf{2}}$ & $(0.047,0.202,0.327)$ & $(0.047,0.264,0.420)$ & $(0.233,0.389,0.420)$ & $(0.047,0.202,0.420)$ \\
$\mathbf{K}_{\mathbf{3}}$ & $(0.150,0.284,0.451)$ & $(0.050,0.284,0.451)$ & $(0.050,0.250,0.451)$ & $(0.050,0.117,0.351)$ \\
$\mathbf{K}_{\mathbf{4}}$ & $(0.229,0.382,0.413)$ & $(0.046,0.229,0.413)$ & $(0.046,0.168,0.321)$ & $(0.138,0.290,0.413)$ \\
$\mathbf{K}_{\mathbf{5}}$ & $(0.054,0.161,0.375)$ & $(0.054,0.232,0.375)$ & $(0.161,0.339,0.482)$ & $(0.054,0.161,0.482)$ \\
$\mathbf{K}_{\mathbf{6}}$ & $(0.048,0.240,0.432)$ & $(0.048,0.208,0.432)$ & $(0.048,0.176,0.432)$ & $(0.144,0.304,0.432)$ \\
$\mathbf{K}_{\mathbf{7}}$ & $(0.054,0.304,0.482)$ & $(0.054,0.339,0.482)$ & $(0.054,0.232,0.482)$ & $(0.054,0.054,0.161)$ \\
$\mathbf{K}_{\mathbf{8}}$ & $(0.138,0.291,0.414)$ & $(0.138,0.291,0.414)$ & $(0.046,0.291,0.414)$ & $(0.046,0.138,0.414)$ \\
$\mathbf{K}_{\mathbf{9}}$ & $(0.250,0.384,0.450)$ & $(0.050,0.217,0.350)$ & $(0.050,0.150,0.350)$ & $(0.050,0.250,0.450)$ \\
$\mathbf{K}_{\mathbf{1 0}}$ & $(0.050,0.252,0.454)$ & $(0.050,0.319,0.454)$ & $(0.050,0.185,0.353)$ & $(0.050,0.218,0.454)$ \\
$\mathbf{K}_{\mathbf{1 1}}$ & $(0.155,0.293,0.465)$ & $(0.052,0.155,0.362)$ & $(0.155,0.327,0.465)$ & $(0.052,0.189,0.362)$ \\
\hline
\end{tabular}


Ardından Tablo 5'de ki kriterlerin önem ağırlıkları ile üçüncü adımda denklem (6), (7) ve (8) yardımıyla Tablo 9'da ağırlıklı normalize bulanık karar matrisi oluşturulmuştur.

Tablo 9. Ağırlıklı Normalize Edilmiş Bulanık Karar Matrisi

\begin{tabular}{lcccc}
\hline Kriterler & $\mathbf{A 1}$ & $\mathbf{A 2}$ & $\mathbf{A 3}$ & $\mathbf{A 4}$ \\
\hline $\mathbf{K}_{\mathbf{1}}$ & $(0.003,0.006,0.017)$ & $(0.003,0.012,0.031)$ & $(0.017,0.026,0.031)$ & $(0.003,0.008,0.024)$ \\
$\mathbf{K}_{\mathbf{2}}$ & $(0.004,0.019,0.031)$ & $(0.004,0.025,0.040)$ & $(0.022,0.037,0.040)$ & $(0.004,0.019,0.040)$ \\
$\mathbf{K}_{\mathbf{3}}$ & $(0.006,0.011,0.018)$ & $(0.002,0.011,0.018)$ & $(0.002,0.010,0.018)$ & $(0.002,0.005,0.014)$ \\
$\mathbf{K}_{\mathbf{4}}$ & $(0.011,0.018,0.019)$ & $(0.002,0.011,0.019)$ & $(0.002,0.008,0.015)$ & $(0.006,0.013,0.019)$ \\
$\mathbf{K}_{\mathbf{5}}$ & $(0.006,0.017,0.039)$ & $(0.006,0.024,0.039)$ & $(0.017,0.035,0.050)$ & $(0.006,0.017,0.050)$ \\
$\mathbf{K}_{\mathbf{6}}$ & $(0.005,0.023,0.041)$ & $(0.005,0.020,0.041)$ & $(0.005,0.017,0.041)$ & $(0.014,0.029,0.041)$ \\
$\mathbf{K}_{\mathbf{7}}$ & $(0.006,0.033,0.053)$ & $(0.006,0.037,0.053)$ & $(0.006,0.025,0.053)$ & $(0.006,0.006,0.018)$ \\
$\mathbf{K}_{\mathbf{8}}$ & $(0.009,0.018,0.026)$ & $(0.009,0.018,0.026)$ & $(0.003,0.018,0.026)$ & $(0.003,0.009,0.026)$ \\
$\mathbf{K}_{\mathbf{9}}$ & $(0.037,0.057,0.067)$ & $(0.007,0.032,0.052)$ & $(0.007,0.022,0.052)$ & $(0.007,0.037,0.067)$ \\
$\mathbf{K}_{\mathbf{1 0}}$ & $(0.007,0.036,0.064)$ & $(0.007,0.045,0.064)$ & $(0.007,0.026,0.050)$ & $(0.007,0.031,0.064)$ \\
$\mathbf{K}_{\mathbf{1 1}}$ & $(0.015,0.028,0.044)$ & $(0.005,0.015,0.034)$ & $(0.015,0.031,0.044)$ & $(0.005,0.018,0.034)$ \\
\hline
\end{tabular}

Dördüncü adımda denklem (9), (10), (11) ve denklem (12), (13), (14) ile fayda ve maliyet kriterleri açısından normalize edilmiş performans değerleri bulunmuştur. Son olarak beşinci adımda programların bulanık olmayan performans değerleri hesaplanarak Tablo 10'deki gibi sıralanmıştır.

Tablo 10. Programların Bulanık Olmayan Performans Değerleri ve Siralama

\begin{tabular}{|c|c|c|c|c|c|c|c|c|}
\hline Alternatifler & \multicolumn{3}{|c|}{$\mathbf{S +}$} & \multicolumn{3}{|c|}{ S- } & $\mathbf{S}$ & Siralama \\
\hline$\overline{A 1}$ & 0.094 & 0.229 & 0.353 & 0.014 & 0.036 & 0.066 & 0.205 & 1 \\
\hline A2 & 0.046 & 0.202 & 0.328 & 0.010 & 0.049 & 0.088 & 0.166 & 2 \\
\hline A3 & 0.061 & 0.183 & 0.331 & 0.041 & 0.073 & 0.088 & 0.154 & 4 \\
\hline A4 & 0.054 & 0.160 & 0.319 & 0.010 & 0.032 & 0.078 & 0.160 & 3 \\
\hline
\end{tabular}

Tablo 10'a göre işletmenin alternatif yeşil tedarikçi geliştirme programları arasından en iyisi (A1) "sertifikalandırma" olarak programı çıkmıştır. Daha sonra ise sırasıyla (A2) "Ar-Ge desteği”, (A4) "uzman desteği ve teknik eğitim" ve (A3) "tedarikçi toplantıları" programları gelmektedir. (A2) ve (A4) programlarının uygulama önceliği kendi içerisinde değişkenlik gösterdiği görülmektedir.

Yeşil tedarikçi geliştirme programları sayesinde tedarikçiler sürekli olarak performanslarını geliştirmeye çalışmaktadırlar. İstatistiksel süreç kontrolleri, sertifikalandırma, Ar-Ge desteği, uzman desteği ve teknik eğitim, düzenli ziyaretler ve ödüllendirmeler ile tedarikçi performansının sürekli iyileştirilmesi takip edilmektedir. Çalışmada işletmenin tedarikçilerine uygulamak istediği alternatif programlar, amaçları gerçekleştirme doğrultusunda karşılaştırılmış ve değerlendirilmiştir. Bu değerlendirmede tedarikçi performansı maliyet, kalite, teknoloji, teslimat, çevre (çevresel tasarım, çevre yönetim sistemi, yeşil imaj, yeşil satın alma) gibi kriterler veya göstergeler ile değerlendirilmektedir. Her bir alternatifin belirli maliyeti olmasının yanında sosyal ve teknik açıdan yapılabilirliği, öngörülen zamanın ve kaynakların yeterliliği yüksektir.

\subsection{Duyarlılı Analizi}

Çalışmanın bu bölümünde kriterlerin önem ağırlıklarının bulanık MOORA yöntemi ile elde edilen sonuçlar üzerindeki etkinliğini test etmek amacıyla 15 farklı durum incelenmiştir. Tablo 11 'de duyarlılık analizi sonuçları verilmiştir.

Tablo 11. Duyarlılık Analizi Sonuçları

\begin{tabular}{l|l|l}
\hline Durum & Kriter ağırlıkları & Alternatif Siralama \\
\hline Ilk durum & Uzman kararlar1 ile & $\mathrm{A} 1>\mathrm{A} 2>\mathrm{A} 4>\mathrm{A} 3$ \\
Durum 1 & $w_{k l}=1, w_{k 2-11}=0$ & $\mathrm{~A} 3>\mathrm{A} 2>\mathrm{A} 4>\mathrm{A} 1$ \\
Durum 2 & $w_{k 2}=1, w_{k l, 3-11}=0$ & $\mathrm{~A} 3>\mathrm{A} 2>\mathrm{A} 4>\mathrm{A} 1$ \\
Durum 3 & $w_{k 3}=1, w_{k l-2,4-11}=0$ & $\mathrm{~A} 1>\mathrm{A} 2>\mathrm{A} 3>\mathrm{A} 4$ \\
Durum 4 & $w_{k 4}=1, w_{k l-3,5-11}=0$ & $\mathrm{~A} 1>\mathrm{A} 4>\mathrm{A} 2>\mathrm{A} 3$ \\
Durum 5 & $w_{k 5}=1, w_{k l-4,6-11}=0$ & $\mathrm{~A} 3>\mathrm{A} 4>\mathrm{A} 2>\mathrm{A} 1$ \\
Durum 6 & $w_{k 6}=1, w_{k l-5,7-11}=0$ & $\mathrm{~A} 4>\mathrm{A} 1>\mathrm{A} 2=\mathrm{A} 3$ \\
Durum 7 & $w_{k 7}=1, w_{k l-6,8-11}=0$ & $\mathrm{~A} 2>\mathrm{A} 1>\mathrm{A} 3>\mathrm{A} 4$ \\
Durum 8 & $w_{k 8}=1, w_{k l-7,9-11}=0$ & $\mathrm{~A} 1=\mathrm{A} 2>\mathrm{A} 3>\mathrm{A} 4$ \\
Durum 9 & $w_{k 9}=1, w_{k l-8,10-11}=0$ & $\mathrm{~A} 1>\mathrm{A} 4>\mathrm{A} 2>\mathrm{A} 3$ \\
Durum 10 & $w_{k l 0}=1, w_{k l-9,11}=0$ & $\mathrm{~A} 2>\mathrm{A} 1>\mathrm{A} 4>\mathrm{A} 3$ \\
Durum 11 & $w_{k l 1}=1, w_{k l-10}=0$ & $\mathrm{~A} 3>\mathrm{A} 1>\mathrm{A} 4>\mathrm{A} 2$ \\
Durum 12 & $w_{h e p s i}=0,0909$ & $\mathrm{~A} 1>\mathrm{A} 2>\mathrm{A} 4=\mathrm{A} 3$ \\
Durum 13 & $w_{k l-3}=0,3333$ & $\mathrm{~A} 3>\mathrm{A} 2>\mathrm{A} 4=\mathrm{A} 1$ \\
\hline
\end{tabular}




\begin{tabular}{l|l|l}
\hline Durum 14 & $w_{k 4-11}=0,125$ & $\mathrm{~A} 1>\mathrm{A} 2=\mathrm{A} 3>\mathrm{A} 4$ \\
Durum 15 & $\sum w_{\text {rastgele }}=1$ & $\mathrm{~A} 1>\mathrm{A} 4>\mathrm{A} 2=\mathrm{A} 3$ \\
\hline
\end{tabular}

Yapılan hesaplamalara göre A1 programı 7 kez, A2 programı 2 kez, A3 programı 5 kez, A4 programı ise 1 kez ilk sırada yer almaktadır. Bu sonuçlar, kullanılan yöntemin sonuçlarının kriter ağırlıklarının değişimine karşı oldukça duyarlı davrandığını ve işletme tarafından yeşil tedarikçi geliştirmede A1 programının ilk sırada uygulanması gerektiğini göstermektedir. Ayrıca bu sonuçlar ile işletmenin tedarikçilerinin gelişimini planlamada içsel yetkinliklerine önem vermesi gerektiği vurgulanmaktadır. Çevre Yönetim Sistemi (ISO 14000), Kalite Yönetim Sistemi (ISO 9001), İş Sağlı̆̆1 ve Güvenliği (ISO 18001) gibi konularda sertifikalandırma süreçleri işletmelerin kurumsal bir yapı kazanmasını sağlamaktadır. Bu tür sertifikalar tedarikçi profesyonelliği ve onun kurumsal yapısı hakkında önemli bilgiler vermektedir.

Yeşil tedarikçi geliştirme programlarını değerlendirirken kullanılan kriterler çok çeşitlilik gösterebilmekedir. Örneğin Tablo 11'e göre alternatif programlar sadece maliyet, imalat çıktısı veya teslimat kriteri ile ilişkilendirildiğinde öncelik (A3) "tedarikçi toplantıları" programının olmaktadır. İşletmeler bir mal veya hizmet alırken farklı tedarikçilerden mutlaka fiyat teklifi almaktadırlar. Birden fazla tedarikçi ile çalışan işletmelerde fiyatın yanında teslim süresi, tedarikçi performansı, ürün çıktısı, yenilikçilik çalışmaları, teknik yeterlilik, esneklik gibi kriterlerde göz önüne alınmaktadır. Dolayısıyla tedarikçi performansı değerlendirmesinde bazı spesifik konularda özel araştırmalar yapmak gerekmekte ve tedarikçiler ile sıklıkla toplantılar organize edilmektedir. Bu toplantılarda sektörün gelişimi, küresel pazarın durumu, yeni ürün projeleri, maliyet rekabetçiliği ve tedarikçi geliştirme programları üzerinde durulmaktadır. Alıcı işletmeler kendi profesyonellik ve kurumsal çalışma anlayışı doğrultusunda tedarikçiler seçmekte ve birlikte çalışmaktadırlar. Bu sayede hedef ve beklentilere cevap verecek tedarikçiler belirlenmektedir (Erdal, 2014: 315).

\section{Yönetimsel Etkileri}

Çalışmanın imalat işletmeleri üzerinde bazı yönetimsel etkileri bulunmaktadır. Öncelikli olarak aynı sektörde bulunan benzer işletmeler kendileri için en uygun yeşil tedarikçi geliştirme programları seçiminde bulunmak istediklerinde önerilen yöntemleri kullanabileceklerdir. Çünkü seçilen en uygun tedarikçi geliştirme programı ürün geliştirme yeteneğinde ve kalitesinde artma, maliyetlerde azalma, tehlikeli ürün üretiminde azalma, satın alma riskinde azalma ve ürün pazar payında artma (Kannan vd., 2013: 365) gibi avantajlar sağlamaktadır. Diğer taraftan çıkan sonuçlara göre tedarikçiler, kendilerini rakiplerine göre kıyaslayabilecekler ve sürdürülebilir ürün ve hizmet sunabilmede kendi performanslarını geliştirebileceklerdir.

İkinci olarak tedarikçiler ile güvene dayalı uzun dönemli bir ilişkide tedarikçilerde görülen eksikliklerin bir daha tekrarlanmaması için önlem alıcı programlar geliştirilmektedir. Yeşil tedarikçi geliştirme programları ile işletmenin bugün ve gelecekteki gereksinimlerini istenilen performanslarda karşılayabilecek tedarikçiler oluşturulabilmektedir. Böylelikle tedarikçiler, ana işletmelerin çevresel, finansal ve sosyal alanlarda yeteneklerini geliştirmesinde katkı sağlayabileceklerdir. Duyarlılık analizi sonuçlarına göre yöneticiler, yeşil tedarikçi değerlendirmede bir standart elde edebileceklerdir.

\section{Sonuç}

Günümüz rekabet ortamında tedarikçilerin işletme stratejilerine ne düzeyde katkı sağladıkları çok fazla tartışılmaktadır. İşletmeler etkin bir yönetim sistemi ile tedarikçilerin sorunlarına çözüm bulma arayışı içerisindedirler. Bu açıdan tedarikçi performansı yönetimi, tedarikçi ilişkileri yönetimi ve tedarikçi geliştirme eğitimi kapsamında uygulanmaktadır. Son yıllarda işletmeler yüksek kalitede hizmet verebilmek, maliyetleri düşürebilmek, çevresel standartlara uyum sağlayabilmek ve yeşil performanslarını artırabilmek maksadıyla tedarikçi geliştirme programlarını uygulamaktadırlar. İyi bir tedarikçi geliştirme programı rekabet avantajının sağlanmasında işletmelere büyük katkı sağlamaktadır. Ayrıca tedarikçi geliştirme programları ile siparişlerin kalite gereksinimlerini karşılama oranı artmakta, zamanında teslim oranı iyileşmekte, ürünlerde hata oranı azalmakta, ortalama envanter maliyeti düşmekte, normal siparişler için tedarik süresi azalmakta, ürün geliştirme seviyesi, ürün satışları ve kalitesi artmaktadır. Literatürde ise yeşil tedarikçi geliştirme üzerine yapılan ve işletmelere yardımcı olabilecek nitelikte çalışmaların sınırlı sayıda olduğu görülmektedir (Bai ve Sarkis, 2010; Blome vd., 2014; Awasthi ve Govindan, 2016). Bu sebeple alıcı işletmeler için belirsizlik ortamında yeşil tedarikçi geliştirme programları seçimi ve değerlendirmesi konusunda nominal grup tekniği ve MOORA yöntemleri ile literatüre bütünleşik yeni bir çalışma sunulmuştur, Ayrıca, gerçek bir işletme üzerinde duyarlılık analizi yapılarak kriter ağırlıklarının sonuçlar üzerindeki etkisi ölçülmüştür. Çalışmada yöntemin bulanıklaştırılarak kullanılması karar vericilere belirli sınırlar içerisinde davranma imkânı vermekte ve bu durum belirsizlik hallerinde esnek bir yap1 sunmaktadır.

Çalışmanın en güçlü yanı önerilen yöntemin yeşil tedarikçi geliştirme programlarının değerlendirilmesi alanında ilk kez uygulanıyor olmasıdır. Fakat bununla birlikte bazı sınırlılıklarda bulunmaktadır. İlk olarak, programların seçimi için belirlenen kriterlerin ve alternatiflerin sayısında artış olması durumu, hesaplama zamanı ve basitliliği etkileyeceğinden dolayı, bu sayılarda her hangi bir değişime gidilmemiştir. İkinci olarak işletmede karar verici konumunda bulunan uzmanların verdikleri cevapların sadece çalışma için değil kurumun genel yönetim ilkeleri kapsamında her zaman arkasında durabilecekleri cevaplar olması umut edilmektedir. Son olarak çalışmada bütün tedarikçilere uygulanabilir tek 
tip tedarikçi geliştirme programları değerlendirilmiştir. Bunun yerine esnekleştirilmiş tedarikçi temelinde özgün programlar gündeme getirilmelidir. Çünkü tedarikçi pazar yapısı ve ürün grupları özgün programların meydana gelmesinde etkili olmaktadır.

Gelecek çalışmalarda farklı yöntemler ile bu çalışmada kullanılan yöntemler arasında performans karşılaştırılması yapılabilir. Örneğin, bulanık TOPSİS, VİKOR gibi yöntemler ile çalışmada kullanılan yöntemlerin birbirilerine göre üstünlüklerini gösteren bir çalışma gerçekleştirilebilir. Diğer taraftan yurt içi ve yurt dişı tedarikçi geliştirme programları arasında farklı yöntemler tercih edilebilmektedir. 


\section{KAYNAKÇA}

Akkaya, G., Turanoğlu, B., Öztaş S. 2015, “An Integrated Fuzzy AHP and Fuzzy MOORA Approach to The Problem of Industrial Engineering Sector Choosing", Expert Systems With Applications, 42 (24), 1-9.

Akman, G. 2015, "Evaluating Suppliers To Include Green Supplier Development Programs Via Fuzzy C-Means and VIKOR Methods", Computers and Industrial Engineering, 86(6). 69-82.

Aktepe, Adnan ve Süleyman Ersöz 2014, AHP-VIKOR ve MOORA Yöntemlerinin Depo Yeri Seçim Probleminde Uygulanması", Endüstri Mühendisliği Dergisi, 25 (1-2), 2-15.

Archana, M, V. Sujatha 2012. "Application of Fuzzy MOORA and GRA in Multi Criterion Decision Making Problems", Internationa lJournal of Computer Applications, 53 (9),46-50.

Awasthi, A., Chauhan, S. S., Goyal, S. K. 2010, "A Fuzzy Multicriteria Approach For Evaluating Environmental Performance of Suppliers", International Journal of Production Economics, 126, 370-378.

Awasthi, A., Govindan, K. 2016, "Green Supplier Development Program Selection Using NGT and VIKOR Under Fuzzy Environment”, Computers and Industrial Engineering, 91, 100-108.

Bai, C., Sarkis, J. 2010, “Green Supplier Development: Analytical Evaluation Using Rough Set Theory”, Journal of Cleaner Production, 18(12), 1200-1210.

Baležentis, Tomas 2011, “A Farming Efficiency Estimation Model Based on Fuzzy MULTIMOORA”, Management Theory and Studies for Rural Business and Infrastructure Development, ResearchPapers, 5 (29), 43-52.

Baležentis, A., Baležentis, T., Brauers, W. K. M. 2012) Personnel Selection Based On Computing With Words and Fuzzy MULTIMOORA”, Expert Systems with Applications, 39 (9), 7961-7967.

Blome, C., Hollos, D., Paulraj, A. 2014, "Green Procurement and Green Supplier Development: Antecedents and Effects On Supplier Performance”, International Journal of Production Research, 52(1), 32-49.

Brauers, W. K. M., Zavadskas, E. K. 2006, "The MOORA Method and Its Application To Privatization In A Transition Economies", Control and Cybernetics, 35 (2), 445-469.

Brauers, W. K. M., Zavadskas, E. K. 2012, "Robustness of MULTIMOORA: A Method For Multi Objective Optimization", Informatica, 23 (1), 1-25.

Büyüközkan, G., Vardaloğlu, Z. 2008, "Yeşil Tedarik Zinciri Yönetimi”, Lojistik Dergisi, 8, 66-73.

Büyüközkan, G., Çifçi, G. 2012, “A Novel Hybrid MCDM Approach Based On Fuzzy DEMATEL, Fuzzy ANP And Fuzzy TOPSIS To Evaluate Green Suppliers", Expert Systems with Applications, 39 (3), 3000-3011.

Chen, C. C., Tseng, M. L., Lin, Y. H. Lin, Z. S. 2010, "Implementation of Green Supply Chain Management In Uncertainty", In Proceedings of International Conference on IE\&EM, IEEE 7-10 December, (260-264).

Chiou, C. Y., Hsu, C. W., Hwang, W. Y. 2008, "Comparative Investigation On Green Supplier Selection of The American, Japanese and Taiwanese Electronics Industry In China", International Conference on IE\&EM, IEEE 8-11 Dec,, (1909-1914).

Dou, Y., Zhu, Q., Sarkis, J. 2014, “Evaluating Green Supplier Development Programs With A Grey-Analytical Network Process-Based Methodology", European Journal of Operational Research, 233(2), 420-431.

Erdal, M. (2014), Satınalma ve Tedarik Zinciri Yönetimi, İstanbul: Beta Basım Yayın.

Fu, X., Zhu, Q., Sarkis, J. 2012, "Evaluating Green Supplier Development Programs At A Telecommunications Systems Provider", International Journal of Production Economics, 40, 357-367.

Govindan, K., Khodaverdi, R., Jafarian, A. 2013, “A Fuzzy Multi Criteria Approach For Measuring Sustainability Performance of A Supplier Based On Triple Bottom Line Approach", Journal of Cleaner Production, 47, 345354.

Govindan, K., Rajendran, S., Sarkis, J., Murugesan, P. 2015, "Multi Criteria Decision Making Approaches For Green Supplier Evaluation and Selection: A Literature Review", Journal of Cleaner Production, 98, 66-83.

Grisi, R. M., Guerra, L., Naviglio, G. 2010, "Supplier Performance Evaluation For Green Supply Chain Management”, Business Performance Measurement and Management, 4, 149-163.

Handfield, R., Walton, S., Sroufe, R., Melnyk, S. 2002, “Applying Environmental Criteria To Supplier Assessment: A Study In The Application of The Analytical Hierarchy Process", European Journal of Operational Research, 141, 70-87.

Hsu, C. W., Hu, A. H. 2009, “Applying Hazardous Substance Management to Supplier Selection Using Analytic Network Process", Journal of Cleaner Production, 17, 255-264.

Humphreys, P. K., Wong, Y. K., Chan, F. T. S. 2003, "Integrating Environmental Criteria In to The Supplier Selection Process", Journal of Materials Processing Technology, 138(1-3), 49-356.

Humphreys, P., McCloskey, A., McIvor, R., Maguire, L., Glackin, C. 2006, "Employing Dynamic Fuzzy Membership Functions To Assess Environmental Performance In The Supplier Selection Process", International Journal of Production Research, 44(12), 2379-2419.

Kannan, D., Khodaverdi, R., Olfat, L., Jafarian, A., Diabat, A. 2013, “Integrated Fuzzy Multi Criteria Decision Making Method and Multi-Objective Programming Approach For Supplier Selection And Order Allocation In A Green Supply Chain", Journal of Cleaner Production, 47, 355-367.

Karande, Prasad ve Shankar Chakraborty 2012, “A Fuzzy MOORA Approach For ERP System Selection”, Decision Science Letters, 1 (1), 11-22. 
Krause, D. R., Handfield, R. B., Tyler, B. B. 2007, “The Relationships Between Supplier Development, Commitment, Social Capital Accumulation and Performance İmprovement”, Journal of Operations Management, 25(2), 528545.

Kuo, R. J., Wang, Y. C., Tien, F. C. 2010, "Integration of Artificial Neural Network and MADA Methods For Green Supplier Selection", Journal of Cleaner Production, 18 (12), 1161-1170.

Lee, A. H. I., Kang, H. Y., Hsu, C. F., Hung, H. C. 2009, “A Green Supplier Selection Model For High-Tech İndustry”, Expert Systems with Applications, 36, 7917-7927.

Lee, C. 2008, "Green Suppliers With Environmental Performance In The Supply Chain Perspective", Asia Pacific Management Review, 13(4), 731-774.

Linton, J. D., Klassen, R., Jayaraman, V. 2007, “Sustainable Supply Chains: An İntroduction”. Journal of Operations Management, 25(1), 1075-1082

Noci, G. 1997, “Designing 'Green' Vendor Rating Systems For The Assessment of A Supplier's Environmental Performance”, European Journal of Purchasing and Supply Management, 3(2), 103-114.

Özçelik, Gökhan, Aydogan, E. Kızılkaya ve Cevriye Gencer (2014), “A Hybrid Moora Fuzzy Algorithm For Special Education and Rehabilitation Center Selection", Journal of Military and Information Science, 2 (3), 53-62.

Shen, L., Olfat, L., Govindan, K., Khodaverdi, R., Diabat, A. 2013, “A Fuzzy Multi Criteria Approach For Evaluating Green Suppliers Performance In Green Supply Chain With Linguistic Preferences”, Resources, Conservation and Recycling, 74, 170-179.

Srivastava, S. K. 2007, "Green Supply-Chain Management: A State-of-The-Art Literature Review”, International Journal of Management Reviews, 9(1), 53-80.

Streimikiene, Delia, Balezentis, Tomas, Krisciukaitiene, Irena ve Alvydas Balezentis 2012, "Prioritizing Sustainable Electricity Production Technologies: MCDM Approach”, Renewable and Sustainable Energy Reviews, 16 (5), 3302-3311.

Tang, C. S., Zhou, S. 2012, "Research Advances In Environmentally and Socially Sustainable Operations", European Journal of Operational Research, 223(3), 585-594.

Tepe, Serap ve Ali Görener 2014, “Analitik Hiyerarşi Süreci ve MOORA Yöntemlerinin Personel Seçiminde Uygulanması”, İstanbul Ticaret Üniversitesi Fen Bilimleri Dergisi, 13 (25). 1-14.

Tseng, M. L., Chiu, A. S. F. 2013, "Evaluating Firms Green Supply Chain Management In Linguistic Preferences", Journal of Cleaner Production, 40, 22-31.

Tuzkaya, G., Ozgen, A., Ozgen, D.,Tuzkaya, U. R. 2009, "Environmental Performance Evaluation of Suppliers: A Hybrid Fuzzy Multi-Criteria Decision Approach, International Journal of Environmental Science and Technology, 6, 477-490.

Uygunturk, H 2015, "Bankaların İnternet Şubelerinin Bulanık MOORA Yöntemi İle Değerlendirilmesi”, Uluslararası Yönetim Íktisat ve Işletme Dergisi, 11 (25), 115-128.

Vachon, S., Klassen, R. D. 2008, "Environmental Management and Manufacturing Performance: The Role of Collaboration In The Supply Chain”, International Journal of Production Economics, 111(2), 299-315.

Vatansever, Kemal ve Metin uluköy (2013), "Kurumsal Kaynak Planlaması Sistemlerinin Bulanık AHP ve Bulanık MOORA Yöntemleriyle Seçimi: Üretim Sektöründe Bir Uygulama”, Celal Bayar Üniversitesi Sosyal Bilimler Dergisi, 11 (2), 274-293.

Yan, G. 2009, "Research On Green Suppliers' Evaluation Based On AHP \& Genetic Algorithm”, In: International Conference on SPS, IEEE ,15-17 May, 615-619.

Yeh, W. C., Chuang, M. C. 2011, "Using Multi Objective Genetic Algorithm For Partner Selection In Green Supply Chain Problems", Expert Systems with Applications, 38, 4244-4253.

Yıldırım, B. Fatih ve Onur Önay 2013, "Bulut Teknolojisi Firmalarının Bulanık AHP - MOORA Yöntemi Kullanılarak Sıralanması”, İstanbul Üniversitesi İşletme Fakültesi İşletme İktisadi Enstitüsü Yönetim Dergisi, 24 (75), 5981. 